\title{
Forage mass and the nutritive value of pastures mixed with forage peanut and red clover
}

\author{
Ricardo Lima de Azevedo Junior ${ }^{1}$, Clair Jorge Olivo ${ }^{2}$, Cláudia Marques de Bem ${ }^{3}$, Priscila \\ Flores Aguirre ${ }^{4}$, Mauricio Pase Quatrin ${ }^{5}$, Marciele Machado dos Santos ${ }^{6}$, Vinicius Felipe \\ Brat $^{6}$, Tiago Horst ${ }^{6}$
}

\footnotetext{
${ }^{1}$ Curso de Pós-Graduação em Zootecnia, Universidade Federal de Santa Maria (UFSM), RS, Brasil.

2 Departamento de Zootecnia - UFSM, RS, Brasil.

${ }^{3}$ Curso de Graduação em Zootecnia - UFSM. Bolsista de iniciação científica CNPq.

${ }^{4}$ Curso de Graduação em Zootecnia - UFSM. Bolsista de iniciação científica FAPERGS.

${ }^{5}$ Curso de Graduação em Agronomia - UFSM

${ }^{6}$ Curso de Graduação em Zootecnia - UFSM.
}

\begin{abstract}
The objective of this research was to estimate three pasture-based systems mixed with elephantgrass + spontaneous growth species, annual ryegrass, for pasture-based system 1; elephantgrass + spontaneous growth species + forage peanut, for pasture-based system 2; and elephantgrass + spontaneous growth species + annual ryegrass + red clover, for pasturebased system 3. Elephantgrass was planted in rows $4 \mathrm{~m}$ apart from each other. During the cool-season, annual ryegrass was sown in the alleys between the rows of elephantgrass; forage peanut and red clover were sown in the alleys between the elephantgrass according to the respective treatment. The experimental design was totally randomized in the three treatments (pasture-based systems), two replicates (paddocks) in completely split-plot time (grazing cycles). Holstein cows receiving $5.5 \mathrm{~kg}$-daily complementary concentrate feed were used in the evaluation. Pre-grazing forage mass, botanical composition and stocking rate were evaluated. Samples of simulated grazing were collected to analyze organic matter (OM), neutral detergent fiber (NDF), crude protein (CP) and organic matter in situ digestibility (OMISD). Nine grazing cycles were performed during the experimental period (341 days). The average dry matter values for pre-grazing and stocking rate were 3.34; 3.46; $3.79 \mathrm{t} / \mathrm{ha}$, and 3.28; 3.34; $3.60 \mathrm{AU} / \mathrm{ha}$ for each respective pasture-based system. Similar results were observed between the pasture-based systems for OM, NDF, CP and OMISD. Considering forage mass, stocking rate and nutritive value, the pasturebased system intercropped with forage legumes presented better performance.
\end{abstract}

Key Words: Arachis pintoi, Lollium multiflorum, Pennisetum purpureum, rotational grazing, Trifolium pratense

\section{Introduction}

Dairy production is a predominant activity in the small agricultural properties of Rio Grande do Sul state, where most of them have in their grass-based pastures a main supplemental resource for the cows. The pastures regular management is based on a conventional strategy production of a simple cultivation of forage plants sometimes subjected to excessively high levels of nitrogen fertilization.

Techniques labeled as sustainable, such as associations with other species, legumes mainly, could possibly minimize utilization of nitrogen fertilizers and still contribute to balancing pasture offer and quality along the crop year. The utilization of forage legumes brings great expectations related to cost reduction and in increases in animal dairy production compared with pure grass pastures, with or without nitrogen fertilization (Assmann et al., 2004). The benefit comes from direct consumption of the forage legume, which enriches and gives variety to cattle diet and from the amount of forage available for the input of nitrogen into the system through its recycling and transfer to the grass (Pereira, 2001; Santos et al., 2002).

Among the forage legumes of potential utilization in forage systems, the forage peanut is highlighted due to its high regrowth capacity and nutritional value above most of other tropical forage legumes (Andrade et al., 2006; Bresolin et al., 2008). Another forage legume that suits the South Region is the red clover, for its remarkable adaptability, palatability and good forage profitability and quality (Montardo et al., 2003).

Research studies reporting the association of grass and forage legumes for pasture finalities are scarce. In the south region of Brazil, particularly, it is necessary to develop deeper studies on the perennial capacity, adaptation, production and contribution to cattle diet, of the peanut 
forage and/or red clover behavior when associated to annual crops of winter cycles like the annual ryegrass, or to tall perennial species like the elephantgrass.

Therefore, this research aimed at the assessment of three forage systems, namely, elephantgrass, annual ryegrass and spontaneous growth species and legumes (forage peanut and red clover) regarding the mass and nutritive value of forage during the agricultural year.

\section{Material and Methods}

The research was conducted in the experimental area of the Department of Animal Science of UFSM, located in the Central Depression region (Santa Maria, RS), map location: $29^{\circ} 43^{\prime} 45.41^{\prime \prime}$ latitude and $53^{\circ} 42^{\prime} 03.62^{\prime \prime}$ longitude, in the period from 05/07/09 to 04/14/10, totaling 341 days. Average temperatures were similar to the region average degrees (Figure 1). For precipitation there were surplus volumes in the spring and summer, except in February and March. The climate is humid subtropical (Cfa) according to the Köppen classification and the soil is classified as red eutrophic argisol (Embrapa, 2006). The treatments consisted of three forage-based systems associated with elephantgrass, spontaneous growth species and the annual ryegrass, while the other ones were associated to forage peanut and red clover.

The experimental area used had 0.78 ha (subdivided in six plots of 0.13 ha each, separated by electrical fences) with elephantgrass (Pennisetum purpureum Schum.), cv. Merckeron Pinda, established for 7 years, in rows $4 \mathrm{~m}$ apart.

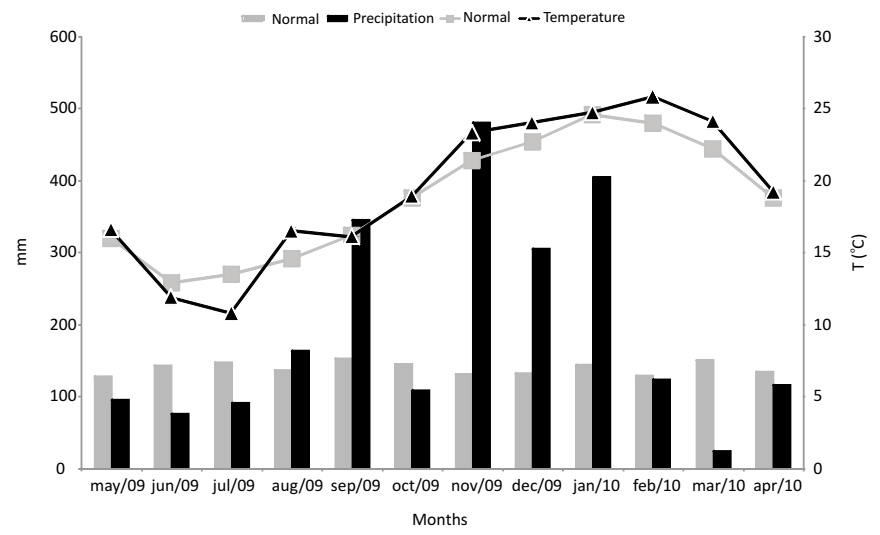

Source: Meteorological Station of Santa Maria, RS, 2010.

Figure 1 - Monthly accumulated rainfall, monthly average temperature and respective average climate measurements for the period from May 2009 to April 2010 .
On May 7, 2009 there was a mechanical harvesting to level areas between the elephantgrass rows, which left a $20 \mathrm{~cm}$ residue, approximately. On May 11, 2009, the annual ryegrass (Lolium multiflorum Lam) (30 kg/ha), cv, Common, was planted by sow broadcasting, in the alleys, after preparation of the experimental area by harrowing (tillage); for the pastures associated with forage legume, new seedlings of red clover (Trifolium pratense L.), cv. Estanzuela 116, at a $3 \mathrm{~kg} / \mathrm{ha}$ proportion were sowed, while the forage peanut (Arachis pintoi Krap. \& Greg.), established for 5 years, was preserved.

Soil analysis presented the following mean values at the beginning of the experimental period: SMP Index 5.7; $\mathrm{P}, 14.5 \mathrm{mg} \mathrm{dm}^{-3} ; \mathrm{K}, 0.13 \mathrm{cmol}_{\mathrm{C}} \mathrm{dm}^{-3} ; \mathrm{Al}^{3+}, 0.9 \mathrm{cmol}_{\mathrm{c}} \mathrm{dm}^{-3}$; $\mathrm{Ca}^{2+}, 5.5 \mathrm{cmol}_{\mathrm{C}} \mathrm{dm}^{-3} ; \mathrm{Mg}^{2+}, 2.3 \mathrm{cmol}_{\mathrm{c}} \mathrm{dm}^{-3}$; OM, $3.0 \%$; base saturation, $54.0 \%$ and aluminum saturation, $12.2 \%$. An amount of $300 \mathrm{~kg} / \mathrm{ha} \mathrm{N}-\mathrm{P}_{2} \mathrm{O}_{5}-\mathrm{K}_{2} \mathrm{O}(5-20-20)$ and $7 \mathrm{~kg} / \mathrm{ha} \mathrm{K}_{2} \mathrm{O}$ were used as fertilizers, divided in two applications: the first in the establishment of the annual ryegrass (in May) and the second after the fourth grazing cycle (in October), and subjected to soil analysis. As covering fertilizer, $45 \mathrm{~kg} / \mathrm{ha}$ $\mathrm{N}$ were used in the form of urea, divided in three applications, after the first, third and fifth grazing cycles.

The criteria employed for the use of pastures during the winter season were based on the development of the annual ryegrass, with animal liberated to enter when the plant was $20 \mathrm{~cm}$ tall, approximately; and in the summer season, when the elephantgrass was between 80 and $100 \mathrm{~cm}$. Before releasing the animals, the forage matter was estimated by the use of the double sampling technique (Wilm et al., 1944), with 20 visual estimations and five cuts. The cuts left the elephantgrass $50 \mathrm{~cm}$ tall, while in the alleys the cut was very shallow. Samples were weighed and blended, and a subsample was produced to estimate botanical composition of pasture and structural composition of elephantgrass, both oven-dried afterwards to determine the partially dried matter (Mannetje, 1978). To estimate the forage matter during the winter season, the total area was roughly divided in $25 \%$ for the elephantgrass and $75 \%$ for the species present between the elephantgrass rows. During the summer season, $38 \%$ of the area was considered occupied by the elephantgrass and $62 \%$ by the species present in the alleys.

The presence of the spittlebug (Deois flavopicta) was noticed when the fourth grazing cycle was over. A biological product (Metarril ${ }^{\circledR}$ - biological pesticide whose active ingredients are (i.a.) Metarhiziumanisopliae fungal spores) was applied to control the population.

After the seventh grazing cycle, in 24 January 2010, the space in the alleys of the experimental area was harvested 
to cut off the advanced stage of development in which some of the spontaneous growth species found in the area were, such as the Paspalum urvillei (the vasey grass).

To estimate the immediate stocking rate, an offer of around 7 and $4 \mathrm{~kg}$ of DM/100 kg of live weight forage was made available for the forage matter in the alleys and the leaf blades matter of the elephantgrass, respectively. The animals used in the test were Holstein dairy cows of $565.24 \pm 33.52 \mathrm{~kg}$ average live weight with an average milk production of $21.5 \pm 6.1 \mathrm{~kg} /$ day. The animals were subjected to a milking routine of two times a day, 7:00 am and 4:00 pm. After the milking, cows were fed complementing nutrients in proportion to their milk production, usually around $5 \mathrm{~kg}$ of concentrate/day. Cows were allowed to graze in the pastures from 9:00 am to 3:30 pm, and from 6:00 pm to 6:30 am.

To determine the pasture chemical composition, field samples that emulated the grazing were extracted after observation of the cows ingestive behavior (Euclides et al., 1992), in each separate plot and after grazing times. The pasture samples were matched (entrance and exit of animals), dried and grounded in a Wiley mill type grinder, packed and analyzed later.

All samples were measured for dry matter content after oven-drying method at $105^{\circ} \mathrm{C}$ until 72 hours, and for ash after burning in muffle furnace at $600{ }^{\circ} \mathrm{C}$ during 3 hours. The organic matter content was calculated as DM - ash. The total nitrogen content was determined by the Kjeldahl method (method 984.13, AOAC, 1995). The neutral detergent fibers content was measured by the method proposed by Van Soest (1991), adapted for utilization in autoclave (Senger et al., 2008). For digestibility in situ, the technique developed by (Mehrez \& Orskov, 1977), which estimates food degradation in artificial porous bags that simulate rumen conditions was chosen.

The experimental design was totally randomized for the three treatments (forage systems), the two areas replicated (plots) in completely split-plot time (grazing cycles). All data were submitted to variability analysis and the means were compared by the Tukey test, at a $5 \%$ level of error probability and correlation, according to the Pearson coefficient. Polynomial regression analyses as function of grazing days were performed for the variables in the pasture forage mass, in the elephantgrass leaf blade mass, in the forage mass in the alleys, of the forage legumes and in the stocking rate. The analyses were performed with the aid of the SAS (Statistical Analysis System, version 8.2) statistic package.

The statistic model referring to the pasture variables analyses studied was represented as: $\mathrm{Y}_{\mathrm{ijk}}=\mathrm{m}+\mathrm{T}_{\mathrm{i}}+\mathrm{R}_{\mathrm{j}}\left(\mathrm{T}_{\mathrm{i}}\right)$ $+\mathrm{C}_{\mathrm{k}}+(\mathrm{TC})_{\mathrm{ik}}+\varepsilon_{\mathrm{ijk}}$, where: $\mathrm{Y}_{\mathrm{ijk}}$ represents dependent variables; i, treatment indexes (forage systems); j, repetition indexes (plots); $\mathrm{k}$, grazing indexes; $\mathrm{m}$ is the average for all reports; $T_{i}$ id the effect caused by the treatments; $R_{j}\left(T_{i}\right)$ is the effect of repetition in treatments (error a); $\mathrm{C}_{k}$ is the effect of grazing cycles; (TC) ${ }_{\mathrm{ik}}$ represents the interaction between treatments and the grazing cycles; $\varepsilon_{\mathrm{ijk}}$ is the residual experimental error (error b).

\section{Results and Discussion}

During the experimental period (341 days), there were nine grazing cycles in both forage systems: four during the cool season and five during the warm season. The grazing intervals varied from 41 to 33 days (during winter and summer seasons, respectively), and the grazing periods from one to two days. Short periods of grazing, up to three days, and resting intervals close to 30 days for the winter cycle species are associated to higher quality forages (Soares et al., 2004). For the hot season grasses, such as the elephantgrass, short periods of occupation and grazing cycles close to 30 days are also associated to the production/animal performance ratio (Deresz et al., 2001).

The pre-grazing forage mass was comparable between the forage systems, with marked difference $(\mathrm{P} \leq 0.05)$ only in the evaluation carried out in September, whose value was higher for pastures consisting of red clover (Table 1 ). The forage mass mean value for the systems was $3.5 \mathrm{t} / \mathrm{ha}$, which is inferior to results observed by Steinwandter et al. (2009), of $5.29 \mathrm{t} / \mathrm{ha}$, under the same procedures and higher nitrogen fertilizer amounts in pastures formed by elephantgrass mixed with ryegrass and white clover (in the cool season) and spontaneous growth species (in the warm season).

No peculiarities were reported for the elephantgrass forage mass present in the rows or in the alleys, either in the intervals between grazing cycles or in the averages of the experimental period. Contrastingly, little forage mass increases could be seen in the association with the red clover, leading to a higher stocking rate $(\mathrm{P} \leq 0.05)$ when compared with the other systems. The same values were observed by Lima et al. (2004) for pure elephantgrass cultivations. Values close to $4.0 \mathrm{UA} /$ ha were observed by Steinwandter et al. (2009). Higher stocking rate, 4.5 UA/ha, was observed by Deresz et al. (2001) on elephantgrass pastures fertilized with $200 \mathrm{~kg}$ of $\mathrm{N}$ in 198 days of estimation with dairy cows.

Despite the relatively low stocking rate reported in this research, emphasis must be given to the fact that the pastures remained in use the whole crop year, with an expressive presence of the elephantgrass (Table 2), 
Table 1 - Pasture forage mass (PFM), pre grazing forage mass (kg of DM/ha), forage mass in the rows (FMR) and in the alleys (FMA) and stocking rate (AU/ha) in three forage systems (FS)

\begin{tabular}{|c|c|c|c|c|c|c|c|c|c|c|c|c|}
\hline \multirow[t]{4}{*}{ Variables } & \multirow[t]{4}{*}{ FS } & \multicolumn{9}{|c|}{ Grazing cycles } & \multirow[t]{4}{*}{ Average } & \multirow[t]{4}{*}{ CV (\%) } \\
\hline & & Jul & Aug & Sep & Oct & Dec & Dec & Jan & Feb & Apr & & \\
\hline & & \multicolumn{6}{|c|}{2009} & \multicolumn{3}{|c|}{2010} & & \\
\hline & & \multicolumn{9}{|c|}{ Forage mass (kg of DM/ha) } & & \\
\hline \multirow{3}{*}{ PFM } & $\mathrm{CO}$ & 1638 & 2322 & $2728 b$ & 3663 & 3582 & 3563 & 4217 & 3904 & 4411 & 3337 & 1.57 \\
\hline & FP & 2326 & 2388 & $2654 b$ & 3268 & 3248 & 3530 & 4320 & 4344 & 5109 & 3465 & \\
\hline & $\mathrm{RC}$ & 2237 & 3242 & $4305 a$ & 3224 & 3206 & 3804 & 4017 & 5130 & 4944 & 3790 & \\
\hline \multirow{3}{*}{ FMR } & $\mathrm{CO}$ & 914 & 476 & 472 & 694 & 1460 & 1286 & 1481 & 1345 & 1226 & 1039 & 9.45 \\
\hline & FP & 1331 & 368 & 459 & 348 & 1601 & 1640 & 1777 & 1923 & 2273 & 1302 & \\
\hline & $\mathrm{RC}$ & 1170 & 680 & 608 & 482 & 1181 & 1750 & 1464 & 2804 & 2003 & 1349 & \\
\hline \multirow{3}{*}{ FMA } & $\mathrm{CO}$ & 724 & 1847 & 2256 & 2968 & 2122 & 2277 & 2737 & 2559 & 3186 & 2297 & 7.29 \\
\hline & FP & 995 & 2020 & 2195 & 2920 & 1646 & 1890 & 2544 & 2422 & 2836 & 2163 & \\
\hline & $\mathrm{RC}$ & 1067 & 2562 & 3697 & 2742 & 2024 & 2054 & 2553 & 2327 & 2942 & 2441 & \\
\hline \multirow{3}{*}{ Stocking rate } & $\mathrm{CO}$ & 0.56 & 1.87 & 2.64 & 3.98 & 2.67 & 4.88 & 5.79 & 3.64 & 3.50 & $3.28 b$ & 1.60 \\
\hline & FP & 0.80 & 2.05 & 2.63 & 3.80 & 2.31 & 4.63 & 5.90 & 3.94 & 4.04 & $3.34 b$ & \\
\hline & $\mathrm{RC}$ & 0.74 & 2.60 & 4.35 & 3.64 & 2.42 & 4.98 & 5.67 & 4.10 & 3.92 & $3.60 \mathrm{a}$ & \\
\hline
\end{tabular}

$\mathrm{CO}$ - control, consisting of elephantgrass (EG) + annual ryegrass (AR) + spontaneous growth species (SGS).

$\mathrm{FP}=\mathrm{EG}+\mathrm{AR}+\mathrm{SGS}+$ forage peanut $(\mathrm{FP})$.

$\mathrm{RC}=\mathrm{EG}+\mathrm{AR}+\mathrm{SGS}+$ red clover $(\mathrm{RC})$.

CV - coefficient variation; DM - dry mnatter; 'a b' - means followed by different letters in the column differ $(\mathrm{P} \leq 0.05)$ by Tukey test.

particularly in the fall season as reported in the estimation of July, represented by an increased biomass of leaf blades. Part of the performance can be credited to the cultivate utilized, which features leaf resistance to blight due to early frosts and a fast recovering capacity expressed by a profuse production of leaves in September (Olivo et al., 1994).

Comparing structural components of the elephantgrass, the similarity of systems becomes clear with special emphasis for the cumulative effect of frosts and low temperatures (Figure 1), with blight of leaves and the distal part of stalks as verified in the estimation performed in August (Table 2). Mean values of leaf blades of $44.35 \%$ are higher than that reported by Steinwandter et al. (2009), of $30.67 \%$, when working with the mentioned cultivar under similar climate conditions and procedures. The small role of this fraction in the dead organic matter concerning grazing cycles included between the end of the summer and fall seasons is distinguishable: an evidence of the strategic function of the elephantgrass in forage planning due to its outstanding production of forage at the beginning of the winter season (Olivo et al., 2009), even if temperatures drop to levels lower than the usual (Olivo et al., 2007).

As for the botanical composition of material present in the alleys of the elephantgrass, differences were observed between the systems concerning the annual ryegrass role, which was higher $(\mathrm{P} \leq 0.05)$ in the pastures mixed with forage peanut and the control, regarding the first and fourth grazing cycles. The leaf blight in part of the forage peanut provided wider light penetration and decrease in plant competition, respectively, as it had happened before with pastures without forage legumes.

As for spontaneous growth species, the growth of the Paspalum spp. represented an average role of 31.37\% during the warm season. The remaining species consisted of Urochloa plantaginea, mainly, Digitaria sanguinalis, Sida santaremnensis, Polygonum persicaria and Conyza bonariensis.

Many pastures depicted differences between the systems, more noticeably in the pastures free of forage legumes, indicating that legumes compete with spontaneous growth species (Lanini et al., 1989; Wiles et al., 1989; Sarrantonio, 1992).

As for the forage legumes, it was reported that each exclusive contribution to the pasture is associated to the development cycle, with observation of forage peanut in six pastures and red clover in seven. Good development of the red clover was probably stimulated by rainfalls during the summer season (Figure 1), a favorable condition to its persistence (Paim, 1994).

An assessment on the forage legumes role that takes into consideration the area occupied in the alleys, $75 \%$ in the winter and $62 \%$ in the summer, reveals values for the forage peanut close to the recommendations of Thomas (1992), of 30\%, which provides balance to nitrogen losses in the system and contributes to fertility of the soil and productivity in long-term. Meanwhile, values for the red clover are close to the recommendations of Cadisch et al. (1994), between 12 and 23\%, adequate to the sustainability 
Table 2 - Percentage of participation of structural components in the elephantgrass, botanical components and dead material (DM) present in the alleys in three forage systems (FS)

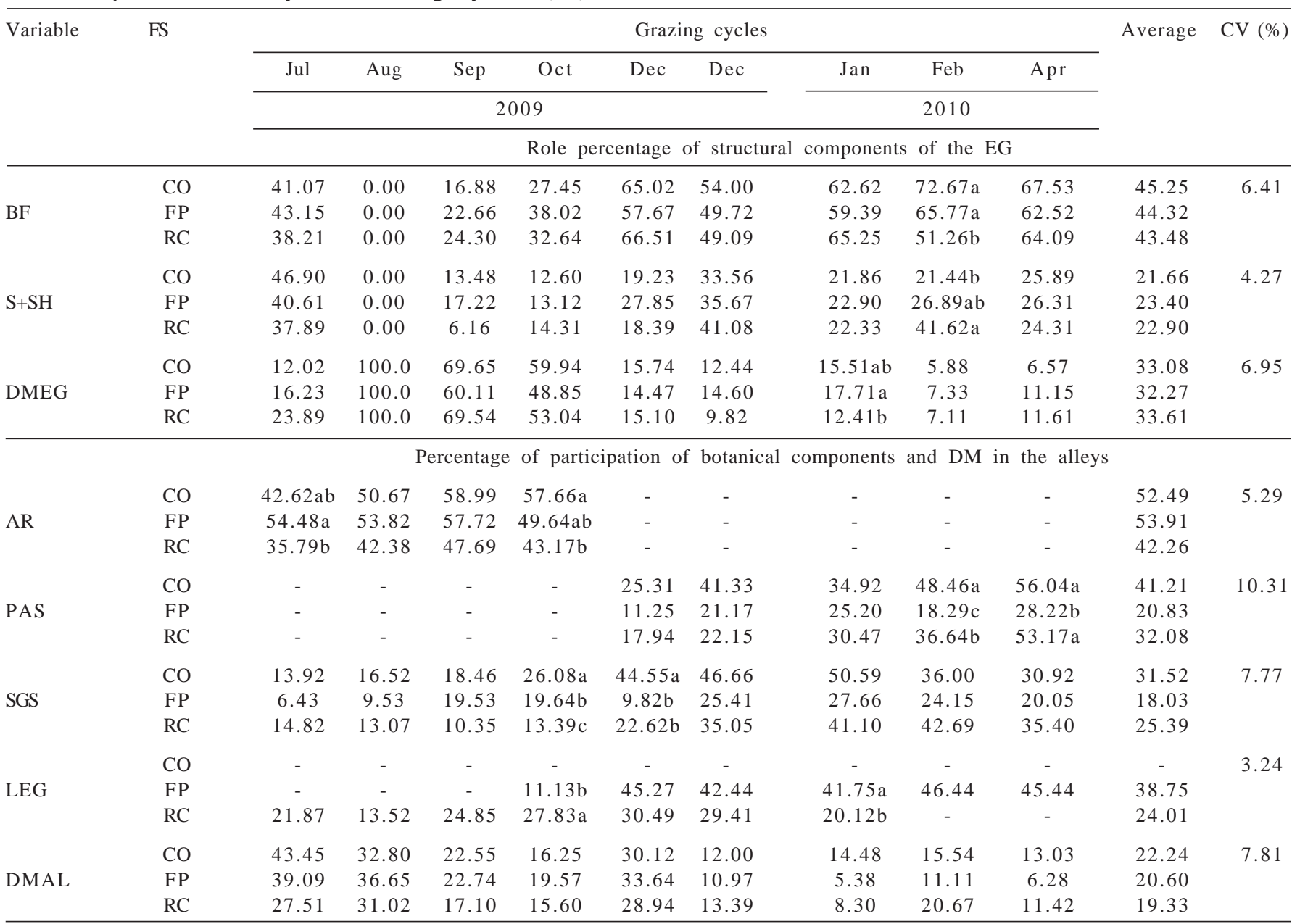

CO - control, consisting of the elephantgrass (EG) + annual ryegrass (AR) + spontaneous growth species (SGS).

$\mathrm{FP}=\mathrm{EG}+\mathrm{AR}+\mathrm{SGS}+$ forage peanut $(\mathrm{FP})$.

$\mathrm{RC}=\mathrm{EG}+\mathrm{AR}+\mathrm{SGS}+$ red clover $(\mathrm{RC})$.

$\mathrm{BF}$ - leaf blade of the EG; S+SH = stalk + sheath of the EG; DMEG = dead material of the EG; PAS - Paspalum spp.; LEG - legume; DOMAL - dead material in the alleys; $\mathrm{CV}$ - coefficient of variation; 'a b' - means followed by different letters in the column $\operatorname{differ}(\mathrm{P} \leq 0.05)$ by Tukey test.

of the forage system. In terms of the whole area, the values reported also fit into the same proportions.

As for dead material, the elephantgrass role was remarkable due to effects expected during the winter season period, contributing to a low stocking rate in the mentioned systems, guaranteed by the annual ryegrass at the beginning of the winter (Figure 2). The forage availability in this period can be enhanced by scheduling winter sowing in the pastures or planting premature cycle species such as oat or rye, mixed with the annual ryegrass (Roso et al., 2000).

Despite the poor forage availability reported in the estimation performed in July (Figure 2), the forage associations created display complementing features, like an increase in the forage mass of the alleys when there is a decrease in the mass of the rows (elephantgrass). Comparatively, distinct models could be identified in the forage legumes; it was linear upward for the forage peanut, while the red clover displayed a square model with an ascending start, with higher stocking rates in estimations performed at the end of the winter, which counted for the difference $(\mathrm{P} \leq 0.05)$ revealed in average stocking rate in relation to the other forage systems (Table 1). On the other hand, although differences are trivial, the forage mass shows little variability during the grazing cycles in the systems associated with forage legumes (Figure 2, Table 1).

In chemical composition (Table 3), there were differences $(\mathrm{P} \leq 0.05)$ in mineral and organic contents only in the estimation performed in August, which depicts the higher values found in pastures associated with forage peanut, possibly due to a larger proportion of annual ryegrass reported for this grazing cycle.

For neutral detergent fiber, there were no differences; the mean value of pastures remained $58.15 \%$, above the 

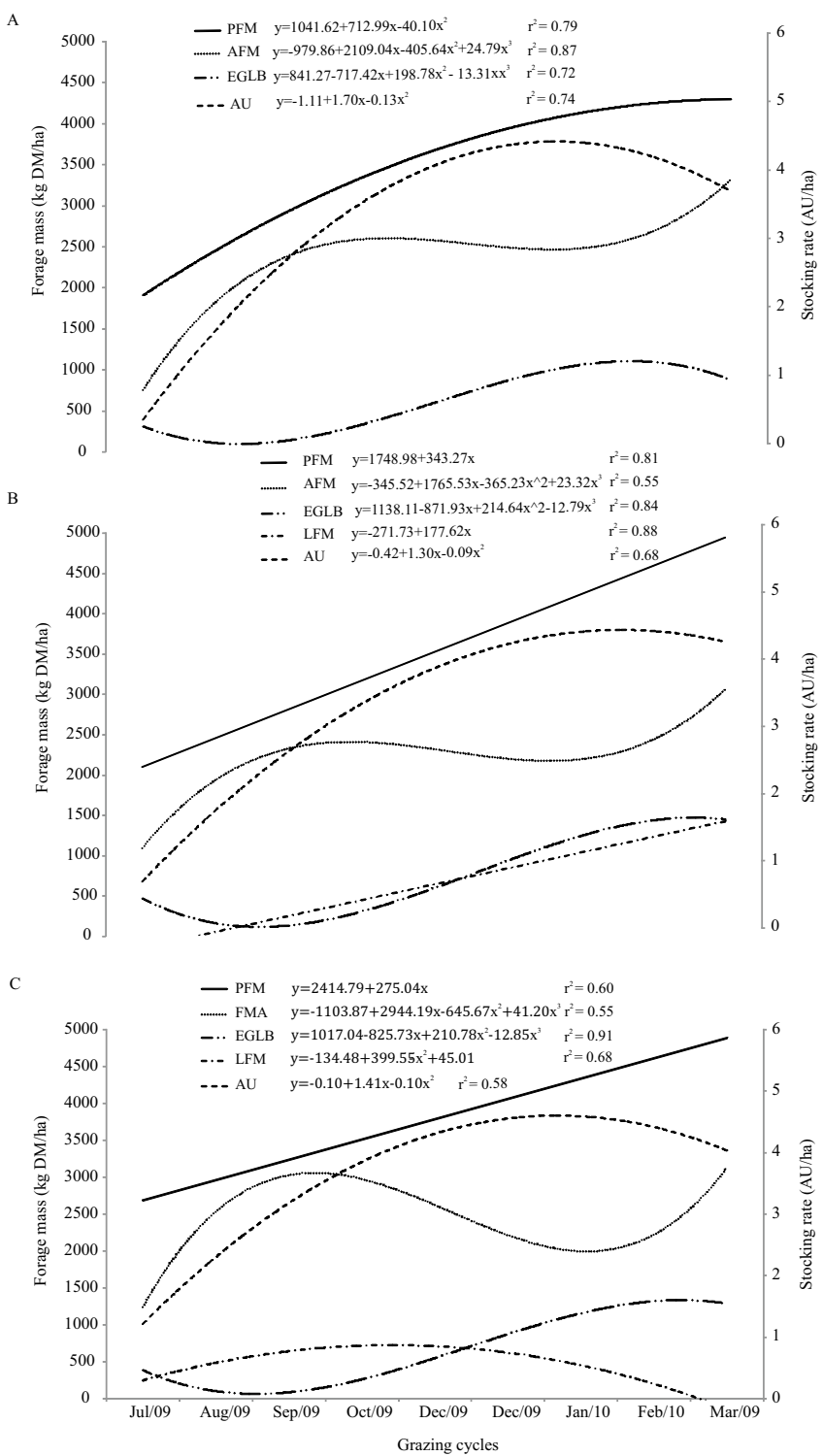

A = control, constituted by elephantgrass $(E G)+$ annual ryegrass $(\mathrm{AR})+$ spontaneous growth species (SGS).

$\mathrm{B}=\mathrm{EG}+\mathrm{AR}+\mathrm{SGS}+$ forage peanut $(\mathrm{FP})$.

$\mathrm{C}=\mathrm{EG}+\mathrm{AR}+\mathrm{SGS}+$ red clover (RC). Santa Maria, RS, 2010.

Figure 2 - Pre-grazing pasture forage mass (PFM), alley forage mass (AFM), elephant grass leaf blade forage mass (EGLB), legume forage mass (LFM) and stocking rate (AU/ha) in three forage systems.

ones reported by Olivo et al. (2009), who obtained mean values of $49.77 \%$ for mixed pastures fertilized like the one in the present research. Gerdes et al. (2005), while studying forage mixtures, found average values of $69.5 \%$ of neutral detergent fiber in the mixture of Aruanagrass (Panicum maximum Jacq. cv. Aruana) with black oats (Avena strigosa Schreb cv. Comum) and annual ryegrass utilizing $200 \mathrm{~kg} / \mathrm{ha} /$ year of nitrogen.

In crude protein, the differences were evident only in grazing cycles occurring in February with high values
( $\mathrm{P} \leq 0.05$ ) for associations with forage peanut in relation to pastures without forage legumes. Protein contents decrease in pastures associated with red clover is due to lack of this forage legume in the period.

Considering all estimations, results point out to a more balanced protein composition in the warm season of systems associated with forage legumes (Cóser \& Cruz Filho, 1989). In cool seasons, the protein balance between the pastures was a consequence of the large contribution of the annual ryegrass (Table 2). Although there were differences expected in the protein composition of pastures mixed with forage legumes, (Smith, 1975; Lascano, 1994), the contents measured were not of substantial significance, considering for this assumption, a very short contribution of the red clover and a potential difference in the palatability of forage legumes (Lascano, 1994).

Regular correlations expected between crude protein contents and neutral detergent fibers were observed $(r=-0.48$; $\mathrm{P}=0.0411$, for pure grass pasture $\mathrm{r}=-0.60 ; \mathrm{P}=0.0089$, for associations with red clover). Association between crude proteins and the contribution (\%) of the forage legume in the alleys was also observed for the red clover $(r=-0.88$; $\mathrm{P}=0.0009$ ), while no results were observed for the association with forage peanut, noticeably because of a more regular and stable participation (Table 2).

There was a difference in the in situ digestibility of the forage organic matter $(\mathrm{P} \leq 0.05)$ on pastures with and without forage legumes in an estimation performed in the beginning of December. When mixed with red clover, the values for digestibility content remained above $80 \%$ between July and December. Meinerz et al. (2008), while estimating the elephantgrass under agroecological and conventional production strategies, reported similar values for crude protein, with averages between 15.11 and $12.99 \%$, and digestibility values below the ones reported in the present research: 70.44 and $66.96 \%$, respectively. Olivo et al. (2009), in study performed on pastures associated to white clover and forage peanut also reported the values of 15.69 and $14.62 \%$ for the protein and of 75.92 and $72.27 \%$ for digestibility, respectively, closer to the ones observed in this research.

Usually observed correlations were reported in the present research, between the in situ digestibility of organic matter and neutral detergent fiber $(\mathrm{r}=-0.48 ; \mathrm{P}=0.0440$, for pastures without forage legume; $\mathrm{r}=-0.65 ; \mathrm{P}=0.0036$, for pastures associated with forage peanut; $\mathrm{r}=-0.54 ; \mathrm{P}=0.0205$, for the ones associated red clover); and of in situ digestibility of organic matter with crude protein $(r=0.63$; $P=0.0047$, for pastures without forage legume; $r=0.58$; $\mathrm{P}=0.0120$, for pastures associated with forage peanut; $r=0.69 ; P=0.0016$, for the ones associated red clover). 
Table 3 - Percentage of organic matter (OM), mineral matter (MM), crude protein (CP), neutral detergent fiber (NDF) and OM in situ digestibility (OMISD) in three forage systems ${ }^{1}$

\begin{tabular}{|c|c|c|c|c|c|c|c|c|c|c|c|c|}
\hline \multirow[t]{3}{*}{ Variable } & \multirow[t]{3}{*}{ FS } & \multicolumn{9}{|c|}{ Grazing cycles } & \multirow[t]{3}{*}{ Average } & \multirow[t]{3}{*}{ CV (\%) } \\
\hline & & Jul & Aug & Sep & Oct & Dec & Dec & Jan & Feb & Apr & & \\
\hline & & \multicolumn{6}{|c|}{2009} & \multicolumn{3}{|c|}{2010} & & \\
\hline \multirow{3}{*}{$\mathrm{OM}$} & $\mathrm{CO}$ & 87.67 & $88.24 b$ & 89.25 & 90.55 & 90.24 & 89.45 & 90.07 & 90.09 & 91.05 & 89.63 & 0.14 \\
\hline & FP & 87.07 & $89.20 a$ & 88.32 & 89.87 & 90.04 & 88.59 & 88.82 & 89.82 & 90.75 & 89.16 & \\
\hline & $\mathrm{RC}$ & 87.04 & $88.81 \mathrm{ab}$ & 88.76 & 88.86 & 89.66 & 90.20 & 90.00 & 90.22 & 91.17 & 89.42 & \\
\hline \multirow{3}{*}{ MM } & $\mathrm{CO}$ & 12.33 & $11.76 \mathrm{a}$ & 10.75 & 9.45 & 9.76 & 10.55 & 9.93 & 9.91 & 8.95 & 10.37 & 1.15 \\
\hline & FP & 12.93 & $10.80 \mathrm{~b}$ & 11.68 & 10.13 & 9.96 & 11.41 & 11.18 & 10.18 & 9.25 & 10.84 & \\
\hline & $\mathrm{RC}$ & 12.96 & 11.19ab & 11.24 & 11.14 & 10.34 & 9.80 & 10.00 & 9.78 & 8.83 & 10.58 & \\
\hline \multirow{3}{*}{ CP } & $\mathrm{CO}$ & 15.84 & 14.89 & 17.31 & 14.94 & 13.31 & 14.62 & 12.64 & 11.69b & 9.54 & 13.86 & 2.01 \\
\hline & FP & 14.78 & 15.89 & 18.45 & 15.17 & 15.05 & 17.32 & 15.51 & 14.19a & 12.11 & 15.39 & \\
\hline & $\mathrm{RC}$ & 14.96 & 17.84 & 17.82 & 16.57 & 15.19 & 14.86 & 12.63 & $12.85 a b$ & 10.31 & 14.78 & \\
\hline \multirow{3}{*}{ NDF } & $\mathrm{CO}$ & 53.74 & 58.75 & 58.48 & 58.01 & 58.23 & 58.14 & 61.26 & 63.66 & 61.12 & 59.02 & 1.93 \\
\hline & FP & 52.98 & 64.97 & 56.13 & 57.94 & 55.60 & 56.11 & 60.33 & 58.88 & 57.74 & 57.85 & \\
\hline & $\mathrm{RC}$ & 53.14 & 59.11 & 54.26 & 54.50 & 53.64 & 59.83 & 61.79 & 59.32 & 62.50 & 57.57 & \\
\hline \multirow{3}{*}{ OMISD } & $\mathrm{CO}$ & 81.32 & 77.71 & 86.56 & $75.82 b$ & $78.04 \mathrm{~b}$ & 81.39 & 73.27 & 76.82 & 74.02 & 78.33 & 1.05 \\
\hline & FP & 79.21 & 74.10 & 84.05 & 81.23ab & $79.61 \mathrm{a}$ & 81.72 & 77.41 & 78.29 & 76.86 & 79.23 & \\
\hline & $\mathrm{RC}$ & 81.39 & 83.35 & 83.40 & $82.73 a$ & $80.42 \mathrm{a}$ & 81.04 & 75.20 & 77.29 & 74.72 & 79.94 & \\
\hline
\end{tabular}

CO - control, constituted by elephantgrass (EG) + annual ryegrass (AR) + spontaneous growth species (SGS).

$\mathrm{FP}=\mathrm{EG}+\mathrm{AR}+\mathrm{SGS}+$ forage peanut $(\mathrm{FP})$.

$\mathrm{RC}=\mathrm{EG}+\mathrm{AR}+\mathrm{SGS}+$ red clover $(\mathrm{RC})$.

CV - coefficient variation; DM - dry mnatter; 'a b' - means followed by different letters in the column differ (P $\leq 0.05)$ by Tukey test.

${ }^{1}$ Samples of simulated grazing cycles, pre and post-grazing averages.

\section{Conclusions}

The utilization of different forage legumes promotes a more balanced forage offer and narrow variation in the nutritional value in the grazing cycles. Considering the stocking rate and the nutritional value, the best results attained are the ones reported for the forage systems including forage legumes.

\section{References}

ANDRADE, C.M.S.; GARCIA, R.; VALENTIM, J.F. et al. Grazing management strategies for massaigrass-forage peanut pastures. 3. Definition of sward targets and carrying capacity. Revista Brasileira de Zootecnia, v.35, n.2, p.352-357, 2006.

ASSMANN, A.L.; PELISSARI, A.; MORAES, A. et al. Produção de gado de corte e acúmulo de matéria seca em sistema de integração lavoura-pecuária em presença e ausência de trevo branco e nitrogênio. Revista Brasileira de Zootecnia, v.33, n.1, p.37-44, 2004.

ASSOCIATION OF OFFICIAL ANALYTICAL CHEMISTS - AOAC. Official methods of analysis. 16.ed. Washington, D.C.: 1995. 1094p.

BRESOLIN, A.P.S.; CASTRO, C.M.; HERTER, F.G. et al. Tolerância ao frio do amendoim forrageiro. Ciência Rural, v.38, n.4, p.1154-1157, 2008.

CADISCH, G.; SCHUNKE, R.M.; GILLER, K.E. Nitrogen cycling in a pure grass pasture and a grass-legume mixture on a red latossol in Brazil. Tropical Grassland, v.28, n.1, p.43-52, 1994.

CÓSER, A.C.; CRUZ FILHO, A.B. Estabelecimento de leguminosas em pastagens de capim-gordura. Revista Brasileira de Zootecnia, v.18, n.5, p.410-416, 1989.
DERESZ, F.; LOPES, F.C.F.; AROEIRA, L.J.M. Influência de estratégias de manejo em pastagem de capim elefante na produção de leite de vacas Holandês x Zebu. Arquivo Brasileiro de Medicina Veterinária e Zootecnia, v.53, p.482-491, 2001. EMPRESA BRASILEIRA DE PESQUISA AGROPECUÁRIA EMBRAPA. Centro Nacional de Pesquisa Agropecuária. Sistema brasileiro de classificação de solos. 2.ed. Rio de Janeiro. EMBRAPA SOLOS, 2006. 306p.

EUCLIDES, V.P.B.; MACEDO, M.C.M.; OLIVEIRA, M.P. et al. Avaliação de diferentes métodos de amostragens sob pastejo. Revista Brasileira de Zootecnia, v.21, n.4, p.691-702, 1992.

GERDES, L.; MATTOS, H.B.; WERNER, J.C. et al. Composição química e digestibilidade da massa de forragem em pastagem irrigada de capim-aruana exclusivo ou sobre-semeado com mistura de aveia preta e azevém anual. Revista Brasileira de Zootecnia, v.34, n.4, p.1098-1108, 2005.

LANINI, W.T.; PITTENGER, D.R.; GRAVES, W.L. et al. Sub clovers as living mulches for managing weeds in vegetables. California Agriculture, v.43, p.25-27, 1989.

LASCANO, C.E. Nutritive value and animal production of forage Arachis. In: KERRIDGE, P.C.; HARDY, B. (Eds.) Biology and Agronomy of forage Arachis. Cali: CIAT, 1994. p.109-121.

LIMA, M.L.P.; BERCHIELLI, T.T.; LEME, P.R. et al. Concentração de nitrogênio uréico plasmático (nup) e produção de leite de vacas mestiças mantidas em gramíneas tropicais sob pastejo rotacionado. Revista Brasileira de Zootecnia, v.33, n.6, p.1616-1626, 2004.

MANNETJE, L.' $t$; Measuring biomass of grassland vegetation. In: MANNETJE, L.'t; JONES, R.M. Field and laboratory methods for grassland and animal production research. Cambridge: CABI Publishing, 1978. p.151-178.

MEHREZ, A.Z.; ORSKOV, E.R. A study of the artificial fibre bag technique for determining the digestibility of feed in the rumen. Journal of Agricultural Science, v.88, p.645-650, 1977.

MEINERZ, G.R.; OLIVO, C.J.; ZIECH, M.F. et al. Composição nutricional de pastagens de capim-elefante submetido a duas 
estratégias de manejo em pastejo. Acta Scientiarum Animal Sciences, v.30, n.4, p.379-385, 2008.

MONTARDO, D.P.; DALL'AGNOL, M.; PAIM, N.R. et al. Forage yield and persistence of red clover progenies in two environments. Scientia Agricola, v.60, n.3, p.447-452, 2003.

OLIVO, C.J.; DIEFENBACH, J.; RUVIARO, C.F. Avaliação da preferência de cultivares de capim elefante pastejados por vacas em lactação. Lavoura Arrozeira, v.47, p.26-30, 1994.

OLIVO, C.J.; CHARÃO, P.S.; PEREIRA, L.E.T. et al. Produtividade e valor nutritivo de pasto de capim elefante manejado sob princípios agroecológicos. Revista Brasileira de Zootecnia, v.36, n.6, p.1729-1735, 2007.

OLIVO, C.J.; ZIECH, M.F.; MEINERZ, G.R. et al. Valor nutritivo de pastagens consorciadas com diferentes espécies de leguminosas. Revista Brasileira de Zootecnia, v.38, n.8, p.1543-1552, 2009.

PAIM, N.R. Melhoramento genético de leguminosas forrageiras. In: PEIXOTO A.M.; MOURA, J.C.; FARIA, V.P. (Coords.). Pastagens: fundamentos da exploração racional. 2.ed. Piracicaba: FEALQ, 1994. p.893-908. (Série atualização em Zootecnia, 10).

PEREIRA, J. M. Produção e persistência de leguminosas em pastagens tropicais. In: SIMPÓSIO DE FORRAGICULTURA E PASTAGENS, 2., 2001, Lavras. Anais... Lavras: UFLA, 2001. p.111-142.

ROSO, C.; RESTLE, J.; SOARES, A.B. et al. Aveia preta, triticale e centeio em mistura com azevém anual: 1. Dinâmica, produção e qualidade de forragem. Revista Brasileira de Zootecnia, v.29, n.1, p.75-84, 2000.

SANTOS, H.P.; FONTANELI, R.S.; BAIER, A.C. Principais forrageiras para integração lavoura-pecuária, sob plantio direto, nas Regiões Planalto e Missões do Rio Grande do Sul. Passo Fundo: EMBRAPA Trigo, 2002. 142p.
SARRANTONIO, M. Opportunities and challenges for the inclusion of soil-improving crops in vegetable production systems. HortScience, v.27, n.1, p.754-758, 1992.

SENGER, C.C.D.; KOZLOSKI, G.V.; SANCHEZ, L.M.B. et. al Evaluation of autoclave procedures for fibre analysis in forage and concentrate feedstuffs. Animal Feed Science and Technology, v.146, p.169-174, 2008.

SMITH, D. Red clover. In: SMITH, R.R. (Ed.) Forage management in the North. Dubeque: Brown Book, 1975. p.103-115.

SOARES, J.P.G.; BERCHIELLI, T.T.; AROEIRA, L.J.M. et al. Estimativas de consumo do capim-elefante (Pennisetum purpureum Schum.), fornecido picado para vacas lactantes utilizando a técnica do óxido crômico. Revista Brasileira de Zootecnia, v.33, n.3, p.811-820, 2004

STEINWANDTER, E.; OLIVO, C.J.; SANTOS, J.C. et al. Produção de forragem em pastagens consorciadas com diferentes leguminosas sob pastejo rotacionado. Acta Scientiarum Animal Sciences, v.31, n.2, p. 131-137, 2009.

THOMAS, R.J. The role of the legume in the nitrogen cycle of productive and sustainable pastures. Grass and Forage Science, v.47, n.1, p.133-142, 1992.

VAN SOEST, P.J.; ROBERTSON, J.B.; LEWIS, B.A. Symposium: carbohydrate methodology, metabolism, and nutritional implications in dairy cattle. Journal of Dairy Science, v.74, n.10, p.3583-3597, 1991.

WILES, L.J.; WILLIAM, R.D.; CRABTREE, G.D. et al. Analyzing competition between a living mulch and a vegetable crop in an interplanting system. Journal of the American Society for Horticulture Science, v.114, p.1029-1034, 1989.

WILM, H.G.; COSTELLO, D.F.; KLIPPE, G.E. Estimating forage yield by the double sampling method. Journal of the American Society for Agriculture, v.36, n.1, p.194-203, 1944. 